\title{
DIAGNOSA KEPERAWATAN PADA PENYAKIT ANEMIA
}

\author{
Syifahanun Septiani
}

syifahanun.s@yahoo.co.id

\section{Latar belakang}

Menurut Roy (1982) diagnosa keperawatan adalah frase singkat atau istilah yang meringkaskan kelompok indikator penting (empiris) yang mewakili pola keutuhan manusia. Anemia merupakan suatu keadaan hemoglobin di dalam darah lebih rendah dari pada nilai normal untuk orang menurut umur dan jenis kelamin. Hemoglobin sendiri adalah zat warna di dalam darah yang berfungsi mengangkit oksigen dan kerbondioksida dalam tubuh.

Menurut WHO tahun 2015, anemia didefinisikan sebagai konsentrasi hemoglobin yang rendah dalam darah. Anemia gizi adalah keadaan kadar hemoglobin darah yang lebih rendah daripada normal sebagai akibat ketidakmampuan jaringan pembentuk sel darah merah dalam memproduksi untuk mempertahankan kadar hemoglobin pada tingkat normal. Anemia gizi besi adalah anemia yang timbul diakibatkan karena kekurangan zat besi sehingga pembentukan sel-sel darah merah dan fungus lain dalam tubuh terganggu.

Diagnosa keperawatan adalah suatu kesimpulan yang dihasilkan dari analisa data (Carpenito, 2009). Diagnosa keperawatan adalah penilaian klinik tentang respon individu keluarga, atau komunitas terhadap masalah kesehatan atau proses kehidupan yang aktual atau potensia. Menurut North American Nursing Diagnosis Assosiation, diagnosa keperawatan memberikan dasar untuk pemilihan intervensi keperawatan untuk mencapai hasil yang merupakan tanggung jawab perawat (1990, dalam Allen, 1998).

Anemia adalah istilah yang menunjukan rendahnya hitungan sel darah merah dan kadar hemoglobin dan hematokrit di bawah normal(Smeltzer,2002:935). Perawat sebagai pemberi asuhan keperawatan diharapkan mampu memberikan pelayanan keperawatan profesional kepada individu, keluarga, dan masyarakat secara mandiri dan kolaborasi dengan tim kesehatan lain. (Kozier, 2005). Dengan demikian anemia bukan merupakan suatu diagnosis atau penyakit, melainkan merupakan pencerminan keadaan suatu penyakit atau gangguan fungsi tubuh dan perubahan patotisiologis yang mendasar yang diuraikan melalui anemnesis yang seksama, pemeriksaan fisik dan informasi laboratorium.

\section{Metode}

Artikel ilmiah ini menggunakan metode membaca dan menganalisa, kajian dari beberapa referensi seperti, jurnal, buku dan e-book. dan juga membandingkan beberapa jurnal yang berhubungan dengan kemampuan perawat dalam memberikan diagnosis keperawatan 
terhadap pasien Anemia. Dari analisi berbagai sumber digunakan Untuk mengetahui kemampuan perawat dalam memberikan diagnosa keperawatan terhadap pasien Anemia.

\section{Hasil}

Diagnosa keperawatan adalah suatu perkumpulan dari masalah pasien yang potensial maupun nyata. Perawat adalah salah satu faktor yang mempengaruhi asuhan keperawatan dan faktor yang menentukan pencapaian pelayanan kesehatan yang optimal. Untuk melaksanakan asuhan keperawatan dengan baik, perawat harus memiliki kemampuan berhubungan dengan klien dan keluarga.

Diagnosa keperawatan ditetapkan berdasarkan analisis dan interpretasi data yang diperoleh dari pengkajian keperawatan klien. Diagnosa keperawatan memberikan gambaran tentang masalah atau status kesehatan klien yang nyata dan kemungkinan akan terjadi, dimana pemecahannya dapat dilakukan dalam batas wewenang perawat. Gordon (1976) mendefinisikan bahwa diagnosa keperawatan adalah masalah kesehatan aktual dan potensial dimana perawat berdasarkan pendidikan dan pengalamannya, dia mampu dan mempunyai kewenangan untuk memberikan tindakan keperawatan. Kewanangan tersebut didasarkan pada standar praktek keperawatan dan etik keperawatan yang berlaku di Indonesia

Awalnya, proses keperawatan dijelaskan melalui empat komponen, yaitu pengkajian, perencanaan, implementasi, dan evaluasi.Akan tetapi,setelah itu berdasarka keputusan (PPNI 2009) perawat mengetahui bahwa makna data pengkajian yang harus diidentifikasi sebelum perencanaandan intervensi dapat saja sudah diiketahui.Saat ini, proses keperawatan di jelaskan sebagai proses siklik lima bagian yang meliputi pegkajian, diagnosis, perencanaan, implementasi , dan evaluasi.( NANDA,2014)

\section{Pembahasan}

Diagnosa memiliki dua arti pertama, diagnosis adalah tahap kedua dari proses keperawatan yang mencangkup analisi data. Kedua, diagnosis adalah label spesifik atau pernyataan yang menggambarkan tentang status kesehatan klien dan keluarganya.(Muhith,2015) Diagnosa keperawatan adalah penilaian klinik tentang respon individu,keluarga,atau komunitas terhadap masalah kesehatan / proses kehidupan yang aktual atau potensial.Diagnosis keperawatan merupakan dasar pemilihan intervensi dalam mencapai tujuan yang telah di tetapkan oleh perawat yang bertanggung jawab. (Muhith,2015)

Diagnosis keperawatan adalah diagnosis yang paling logis terjadi ketika terjadi suatu kondisi medis tertentu. Tentu saja seorang pasien dengan satu kondisi medis tidak akan mempunyai semua diagnose keperawatan yang di tampilkan. Pilih hanya diagnosa keperawatan yang di konfirmasikan dengan data pengkajian. Lebih jauh lagi, daftar yang telah di pilih ini harus telah di pertimbangkan dengan tidak berlebihan. Mungkin saja terjadi bahwa seorang pasien 
dengan suatu kondisi medis tertentu akan mempunyai diagnosa keperawatan yang tidak terdaftar dalam daftar.Karena pasien mewakili respon manusia ynang unik,diagnosa keperawatan tidak dapat di ramalkan berdasarkan kondisi medis saja.(Hidayat,2008)

Didalam diagnose keperawatan juga ada beberapa tahapan yang berbeda beda antara lain:

a) Klasifikasi dan Analisa Data

Pengelompokkan data adalah mengelompokkan data-data klien atau keadaan tertentu di mana klien mengalami permasalahan kesejahteraan atau keperawatan berdasarkan criteria permasalahannya.Pengelompokkan data dapat di susun berdasarkan pola respon manusia (taksonomi NANDA)dan atau pola fungsi kesehatan.

b) Interprestasi data klien

Masalah klien merupakan keadaan atau situasi dimana klien perlu bantuan untuk mempertahankan status kesehatannya,

c) Memvalidasi data

Adalah menghubungkan dengan klasifikasi gejala dan tanda tanda yang kemudian merujuk kepada ketepatan data.Untuk kelengkapan dan ketepatan data,kerja sama dengan klien sangat penting untuk saling percaya,sehingga mendapatkan data yang tepat.

d) Merumuskan diagnose keperawatan

Setelah perawat mengelompokkan,mengidentifikasi,dan memvalidasi data-data yang signifikan, maka tugas perawat pada tahap ini adalah merumuskan suatu diagnosis keperawatan.Diagnosis keperawatan dapat bersifat actual, resiko, kemungkinan, kesejahteraan, dan sindrom. ( Muhith,2015).

Dengan diagnosa keperawatan sebagai dasar dari keperawatan ,perawat perlu mengembangkan kompetensi diagnostik dalam rangka menjadi penegak diagnosis yang baik.(NANDA,2014). Seorang perawat bertanggung jawab secara langsung dalam pembuatan diagnosa keperawatan.Perawat juga bertanggung jawab pada pengobatan,dengan mengaplikasikan prinsip enam benar yaitu, benar obat, benar dosis, benar klien, benar cara, benar waktu, dan benar dokumentasi.(Haryanto,2007)

Kategori diagnose keperawatan terdiri dari:

1. Diagnosa Keperawatan Aktual

Diagnosa keperawatan aktual menurut NANDA adalah diagnosa yang menyajikan keadaan klinis yang telah divalidasikan melalui batasan karakteristik mayor yang diidentifikasi. Diagnosa keperawatan mempunyai empat komponen : label, definisi, batasan karakteristik, dan faktor yang berhubungan. Label merupakan deskripsi tentang definisi diagnosis dan batasan karakteristik.

2. Diagnosa Keperawatan Risiko atau Risiko Tinggi 
Menurut NANDA, diagnosa keperawatan risiko adalah keputusan klinis tentang individu, keluarga atau komunitas yang sangat rentan untuk mengalami masalah dibanding individu atau kelompok lain pada situasi yang sama atau hampir sama.

Diagnosa keperawatan ini mengganti istilah keperawatan potensial dengan menggunakan "risiko terhadap atau risiko tinggi terhadap". Validasi untuk menunjang diagnosis resiko tinggi adalah faktor resiko yang memperlihatkan keadaan dimana kerentanan meningkat terhadap klien atau kelompok dan tidak menggunakan batasan karakteristik. Penulisan rumusan diagnosis ini adalah : PE (problem \& etiologi).

3. Diagnosa Keperawatan Kemungkinan

Menurut NANDA, diagnosa keperawatan kemungkinan adalah pernyataan tentang masalah yang diduga masih memerlukan data tambahan dengan harapan masih diperlukan untuk memastikan adanya tanda dan gejala utama adanya faktor resiko.

4. Diagnosa Keperawatan Sejahtera

Menurut NANDA, diagnosa keperawatan sejahtera adalah ketentuan klinis mengenai individu, kelompok, atau masyarakat dalam transisi dari tingkat kesehatan khusus ke tingkat kesehatan yang lebih baik. Cara pembuatan diagnosa ini adalah dengan menggabungkan pernyataan fungsi positif dalam masing-masing pola kesehatan fungsional sebagai alat pengkajian yang disahkan. Dalam menentukan diagnosa keperawatan sejahtera, menunjukkan terjadinya peningkatan fungsi kesehatan menjadi fungsi yang positif.

5. Diagnosa Keperawatan Sindrom

Menurut NANDA, diagnosa keperawatan sindrom adalah diagnosa yang terdiri dari sekelompok diagnosa keperawatan aktual atau resiko, yang diduga akan muncul karena suatu kejadian atau situasi tertentu.

Menurut NANDA ada 2 diagnosa keperawatan sindrom

1) Sindrom trauma pemerkosaan

Contoh : cemas, takut, sedih, gangguan pola istirahat dan tidur.

2) Resiko sindrom penyalahgunaan

Contoh : Resiko Konstipasi, resiko perubahan fungsi pernafasan, resiko infeksi, resiko gangguan aktifitas

\section{Penutup}

a. Kesimpulan

Diagnosis Keperawatan merupakan keputusan klinik tentang respon individu, keluarga dan masyarakat tentang masalah kesehatan aktual atau potensial, dimana berdasarkan pendidikan dan pengalamannya, perawat secara akontabilitas dapat mengidentifikasi dan memberikan intervensi secara pasti untuk menjaga, 
menurunkan, membatasi, mencegah dan merubah status kesehatan klien (Carpenito, 2000; Gordon, 1976 \& NANDA).

Diagnosis keperawatan ditetapkan berdasarkan analisis dan interpretasi data yang diperoleh dari pengkajian keperawatan klien. Diagnosis keperawatan memberikan gambaran tentang masalah atau status kesehatan klien yang nyata (aktual) dan kemungkinan akan terjadi, dimana pemecahannya dapat dilakukan dalam batas wewenang

b. Saran

Mahasiswa keperawatan harus lebih menerapkan dan memahami dengan teliti konsep diagnosis keperawatan dalam melaksanakan diagnosis keperawatan untuk meningkatkan kualitas yang baik dan benar. 


\section{DAFTAR PUSTAKA}

Simamora, R. H., Bukit, E., Purba, J. M., \& Siahaan, J. (2017). Penguatan kinerja perawat dalam pemberian asuhan keperawatan melalui pelatihan ronde keperawatan di rumah sakit royal prima medan. Jurnal pengabdian kepada masyarakat, 23(2), 300-304.

Simamora, R. H. (2005). Hubungan Persepsi Perawat Pelaksana Terhadap Penerapan Fungsi Pengorganisasian Yang Dilakukan Oleh Kepala Ruangan Dengan Kinerjanya Diruang Rawat Inap RSUD Koja Jakarta Utara (Doctoral dissertation, Tesis FIK UI, Tidak dipublikasikan).

NANDA,(2014), Diagnosis Keperawatan Defenisi dan Klasifikasi, EGC:Jakarta ( terjemahan )

NANDA Internasional. 2015. NANDA International Inc. Diagnosis Keperawatan: Definisi \& Klasifikasi 2015 -2017, Edisi 10. Jakarta: EGC

Price, S. A., \& Wilson, L. M. (2005). Patofisiologi: Konsep klinis proses-proses penyakit. (Brahm U. Pendit: Penerjemah). Ed. 6. Jakarta: EGC.

Perry, A. G., \& Potter, P. A. (2009). Potter and perry's fundamentals of nursing Australian

Potter, P. A., \& Perry, A. G. (2005) Buku Ajar Fundamental Keperawatan: Konsep, Proses dan Praktek (edisi 4). Jakarta : Penerbit Buku Kedokteran EGC.

Potter, P. A., \& Perry, A. G., (2013). Fundamentals of nursing. (8th ed). Elsevier.

Carpenito, L. J. 1999. Rencana Asuhan keperawatan dan dokumentasi keperawatan, Diagnosis Keperawatan dan Masalah Kolaboratif, ed. 2. EGC :Jakarta

Smeltzer, A. C., \& Bare, B. G. 2002. Buku ajar keperawatan medical bedah Brunner \& Suddart. (Agung Waluyo: Penerjemah). Ed. 8. Jakarta: EGC.

Mery, S. (2018). Asuhan Keperawatan Pada Ny. A (30 Tahun) Dengan Kanker Ovarium Stadium Ii B+ Anemia Sedang Dan Penerapan Evidance Based Nursing Practice Relaksasi Nafas Dalam Dan Distraksi Dengan Latihan Lima Jari Di Ruangan Ginekologi Onkologi Rsup Dr. M. Djamil Padang (Doctoral dissertation, Universitas Andalas).

Kozier, B., Berman, A. And Shirlee, alih bahasa Pamilih Eko Karyuni, dkk. 2010. Buku Ajar Fundamental Keperawatan Konsep Proses dan Praktik edisi VII Volume 1. Jakarta : EGC 
Stanhope, M., \& Lancaster, J. (2016). Public Health Nursing. 9 th ed. St. Louis, MO: Mosby-Elsevier 